A HISTORY OF THE BRITISH ISLES 


\section{Also by Jeremy Black}

British Foreign Policy in the Age of Walpole

The British and the Grand Tour

Natural and Necessary Enemies: Anglo-French Relations in the Eighteenth Century

The English Press in the Eighteenth Century

The Collapse of the Anglo-French Alliance, 1727-31

Eighteenth-Century Europe, 1700-89

Robert Walpole and the Nature of Politics in Early EighteenthCentury Britain

The Rise of the European Powers, 1679-1793

A System of Ambition? British Foreign Policy, 1660-1800

A Military Revolution? Military Change and European Society, 1550-1800

Culloden and the ' 45

War for America. The Fight for Independence, 1775-1783

Pitt the Elder

The British Abroad: The Grand Tour in the Eighteenth Century History of England

The Politics of Britain, 1688-1800

European Warfare, 1660-1815

Convergence or Divergence? Britain and the Continent

British Foreign Policy in an Age of Revolutions, 1783-93

The Cambridge Illustrated Atlas of Warfare: Renaissance to Revolution

Illustrated History of Eighteenth-Century Britain 


\title{
A History of the British Isles
}

\author{
Jeremy Black
}

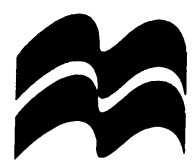


(C) Jeremy Black 1996

Softcover reprint of the hardcover 1st edition 1996 978-0-333-66281-6

All rights reserved. No reproduction, copy or transmission of this publication may be made without written permission.

No paragraph of this publication may be reproduced, copied or transmitted save with written permission or in accordance with the provisions of the Copyright, Designs and Patents Act 1988, or under the terms of any licence permitting limited copying issued by the Copyright Licensing Agency, 90 Tottenham Court Road, London W1P 9HE.

Any person who does any unauthorised act in relation to this publication may be liable to criminal prosecution and civil claims for damages.

First published 1996 by

MACMILLAN PRESS LTD

Houndmills, Basingstoke, Hampshire RG21 6XS

and London

Companies and representatives

throughout the world

ISBN 978-1-349-24976-3 ISBN 978-1-349-24974-9 (eBook)

DOI 10.1007/978-1-349-24974-9

A catalogue record for this book is available from the British Library.

$\begin{array}{lllllllll}10 & 9 & 8 & 7 & 6 & 5 & 4 & 3 & 2\end{array}$

$\begin{array}{lllllllll}05 & 04 & 03 & 02 & 01 & 00 & 99 & 98 & 97\end{array}$

Copy-edited and typeset by Povey-Edmondson

Okehampton and Rochdale, England

Published in the United States of America 1996 by

ST. MARTIN'S PRESS INC.,

Scholarly and Reference Division

175 Fifth Avenue, New York, N.Y. 10010

ISBN 978-0-312-16063-0 
To Timothy 


\section{Contents}

List of Maps ix

List of Plates $\quad \mathrm{x}$

Preface $\quad$ xi

Introduction xiii

Maps xviii

1 Pre-Roman and Roman Britain 1

2 Saxons, Vikings and Celts, AD 400-1066 7

3 The Middle Ages $\quad 27$

4 The Sixteenth Century $\quad 87$

$\begin{array}{lrr}5 & 1603-88 & 119\end{array}$

\begin{tabular}{lrr|r}
6 & $1689-1815$ & 143
\end{tabular}

7 Age of Reform and Empire, 1815-1914 187

8 The Twentieth Century, 1914-96 249

9 The British Isles Today 309

Selected Further Reading 327 


\section{List of Maps}

1 Roman Britain

2 Anglo-Saxon Britain

3 Medieval British Isles

4 The Sixteenth Century

5 The Civil Wars, 1638-1691

6 British Industrialization and Reform, 1750-1900

7 The British Empire in 1914 


\section{List of Plates}

1. The 'Long Man of Wilmington', Sussex (Barnaby's Picture Library)

2. Head of Mithras (Museum of London)

3. A detail from The Book of Kells (Trinity College' Library, Dublin)

4. 'Scissors' arch, Wells Cathedral, Somerset (J. Allan Cash Ltd)

5. The Battle of Agincourt, 1415 (Mansell Collection)

6. The 'Darnley Portrait' of Elizabeth 1, attributed to Federigo Zuccaro (private collection)

7. Charles I and James, Duke of York, by Sir Peter Lely (Collection of the Duke of Northumberland)

8. Christ Church, Spitalfields (Mansell Collection)

9. The Secret Portrait of Bonnie Prince Charlie (West Highlands Museum, Fort William)

10. The Peterloo Massacre, Manchester, 1819 by Phiz (Mansell Collection)

11. Bargoe Coal Mine, Glamorganshire (Barnaby's Picture Library)

12. The Easter Rising, 1916 (Popperfoto)

13. Painting of the South Downs by Frank Newbould (Imperial War Museum)

14. Royal Scots Fusiliers in Burma, 1944 (Imperial War Museum)

15. George Square, Glasgow, 1995 (J. Allan Cash Ltd)

16. The Mandir Temple, Neasden, 1995 (Camera Press Ltd) 


\section{Preface}

In some respects this has been the most interesting and most difficult book that I have attempted. Most interesting because I have had to read so widely, most difficult because of the discipline of writing in accordance with particular guidelines and to a tight word-limit. What has been discarded in endless redrafting could have made several books, which shows not only the richness and variety of the history of the British Isles, but also the different ways in which it could be approached. Any history inevitably invites suggestions about different approaches, contrasting arguments, divergent conclusions. The history of the British Isles is the history of the English, Irish, Scots and Welsh. Britain itself has a shorter history as a united state and it is important to place due weight on separate and diverse national traditions. Particular emphasis has been placed on the history of Wales, too often subsumed into accounts of English history but an area of great interest because it was the 'Celtic' area most exposed to English pressure and rule. At the risk of anachronism, terms such as England, Wales, Scotland, Ireland, France and East Anglia are used throughout so that modern readers can better understand the areas they refer to. Britain is generally used to denote England, Wales and Scotland. It is sometimes termed Great Britain. The British Isles is the term used for Britain and Ireland. Ireland refers to the geographical area currently divided between the Republic of Ireland, and Northern Ireland which is a part of the United Kingdom, the state otherwise comprised of Britain.

This book is dedicated to my son Timothy, but while writing my thoughts have often turned to those who taught me English history, to David Griffiths at Haberdashers', and to Tim Blanning, Martin Brett, Marjorie Chibnall, John Morrill, Jonathan Riley-Smith and John Walter at Cambridge. Many thanks to Paul Hammond, Michael Jones and Kenneth Morgan for letting me quote from their work. I am most grateful to Ian Archer, Stuart Ball, Chris Bartlett, Sarah Black, John Blair, John Bourne, George Boyce,

Richard Brown, Duncan Bythell, Tony Carr, P.J. Casey, Rees Davies, John Davis, John Derry, Grayson Ditchfield, Sean Duffy, 
Alan Ford, Robin Frame, William Gibson, Ralph Griffiths, Steve Gunn, David Gwynn, Robert Harris, Paul Harvey, Alan Heesom, Philip Jenkins, Gareth Elwyn Jones, J. Gwynfor Jones, John R. Kenyon, Keith Laybourne, David Loades, Alex Murdoch, Jon Parry, Murray Pittock, John Plowright, Bernard Porter, Michael Prestwich, Nigel Ramsay, David Rollason, Nigel Saul, Geoffrey Searle, Peter Shilston, Henry Summerson, Christopher Williams and John Young, for commenting on sections of earlier drafts. I am most grateful for the secretarial assistance of Wendy Duery.

JEREMY BLACK 


\section{Introduction}

That the past, our past, can be seen in so many different lights adds to its fascination. There is not only the question of what to discuss, but the problem of how best to do so. If it is difficult enough for us to establish the course of history, it is even harder to assess causes. This is particularly a problem with a book of this scale. There is a powerful tendency, when writing a history that stretches over more than two millennia but relatively few pages, to shape the past into patterns and to stress the beneficial nature of the changes that have occurred. This Whiggish approach to British history was particularly dominant in the nineteenth and early twentieth centuries; it emphasised a Protestant identity for the nation, respect for property, the rule of law and parliamentary sovereignty as a means to secure liberty and order, and a nationalistic self-confidence that combined a patriotic sense of national uniqueness with a xenophobic contempt for foreigners, especially Catholics. The positive contribution of Protestantism and liberty to prosperity and social development was stressed, but a very partial account of the latter was offered, concentrating on the growth of a strong middle class.

In modern academic circles Whig history is apparently dead, displaced by the scholarly developments of the last sixty years. At the popular level, however, traditional history and historical images are still popular, generally reflect Whiggish notions and often have little to do with academic developments. In addition, the academic works that sell best and are most accessible to the general reading public are generally those that are written in a traditional fashion. Biographies and narratives are at a premium. Narrative history is especially popular. This can be seen in child, adolescent, and adult reading patterns, and there is a parallel in literature, where continued popular preferences defy powerful academic literary fashions. The persistent popularity of the detective novel, with its stress on the role of the individuals and chance, and with a strong narrative structure, and, in most cases, its strong 
moral element, is especially noteworthy. The genre offers exciting, often exemplary, stories, which are precisely what are sought by most readers of history. In combination, narrative and the Whig approach offer a readily accessible means to produce a clear account of a highly complex subject: human history.

This book, however, seeks to avoid an emphasis on inevitability. It is important to appreciate that choices have always existed, that policy was not pre-ordained by the 'structures' of economic or other circumstances, that contingencies and the views of individuals were of consequence. It is necessary to grasp the uncertainties of the past, the roles of chance and perception; to restore a human perspective to an historical imagination too often dominated by impersonal forces. If this can lead to greater difficulties in posing and answering questions of the relationships between change and continuity, the short term and the long, it is appropriate to point out that history is not an unbroken mirror reflecting our views, but a fractured glass turning in the wind, with pieces missing or opaque and a general pattern that is difficult to distinguish and impossible to do so to general satisfaction.

The selection of central themes is therefore in large part a personal response to the multifaceted nature of the past. Two emerge clearly: first the political relations both between the constituent parts of Britain and between them and the rest of Europe; and secondly the impact of technology. The latter is particularly important and becoming more so. The impact of man on his environment has been far more insistent in the age of industrialisation and urbanisation than hitherto. People no longer have to live by the sweat of their brow; they are more likely to sit in an office, manipulating electronic machinery, whether manufacturing goods or working in the financial or service industries. They do not face starvation if they fall ill. They take longevity, perhaps even prosperity, for granted. People themselves have changed. Inoculations to prevent serious diseases are now universal. Mechanical and chemical contraception has led to the replacement of earlier patterns of sexual activity and procreation. Technical and medical advances have led to the ability effectively to replace parts of the body, such as hips. Much work is currently under way on creating artificial knee joints, a far more complex task. People look different: they are taller than in the past; teeth have been filled or crowned or replaced by dentures; the water is fluoridated. Clothes are made from man- 
made or enhanced fibres; food is processed, coloured and preserved as a result of the combination of modern science and mass-production techniques.

These changes are emphasised in the chapter on the twentieth century, but they are, of course, more general, as have been shifts towards a more immediate 'mass culture'. Widespread literacy in the nineteenth century, followed by the spread of new media in the twentieth, led to a dynamic, constantly renewed relationship between the producers and consumers of information and images. This was subversive of earlier means of disseminating and inculcating ideas. A vastly expanded press, and new media such as the television, did not necessarily lead to the spread of radical ideas they could equally serve to reiterate conservative views - but, by regularly providing information and stimuli, they played a major role in a democratisation or equalisation of society that has been a predominant theme over the last century and a half. In the nineteenth century the newspaper became an accepted means for the pursuance of disputes, possibly contributing to a more peaceful and public means of conducting political, social, economic and religious disagreements. Democratisation was not the same as democracy, publicity did not entail the public nature of all politics, but in the twentieth century the information presented to the public has become more extensive and its impact more insistent. Whereas Edward VIII's relationship with Mrs Simpson (later the Duchess of Windsor) in the 1930s was known only to a restricted circle, the same has not been true of the activities of his grand-nephew, Prince Charles. Politicians today press avidly for equal exposure on television, but there are also worries about privacy.

This book itself is a testimony to changing circumstances. Technology is all-pervasive: the use of a word processor permitted frequent redrafting. There is also the clear sense that it is necessary to produce a work that is accessible to a wide audience. Consumer choice is crucial, and censorship, or the need to follow a 'party line', is a not a factor. Indeed, it is the freedom with which this book has been written that is the most encouraging feature of this work. In Britain it is possible to write a book of this type without the problems and fears that an author would experience in much of the world. There is no room for triumphalism: the position may not last. The situation in Northern Ireland scarcely offers encouragement about the use of the past. Nevertheless, it is part of the 
xvi

strength of much of British society that it can look at itself and its past without complacency or the need to reiterate national myths. Would that that were true more widely.

JEREMY BLACK 


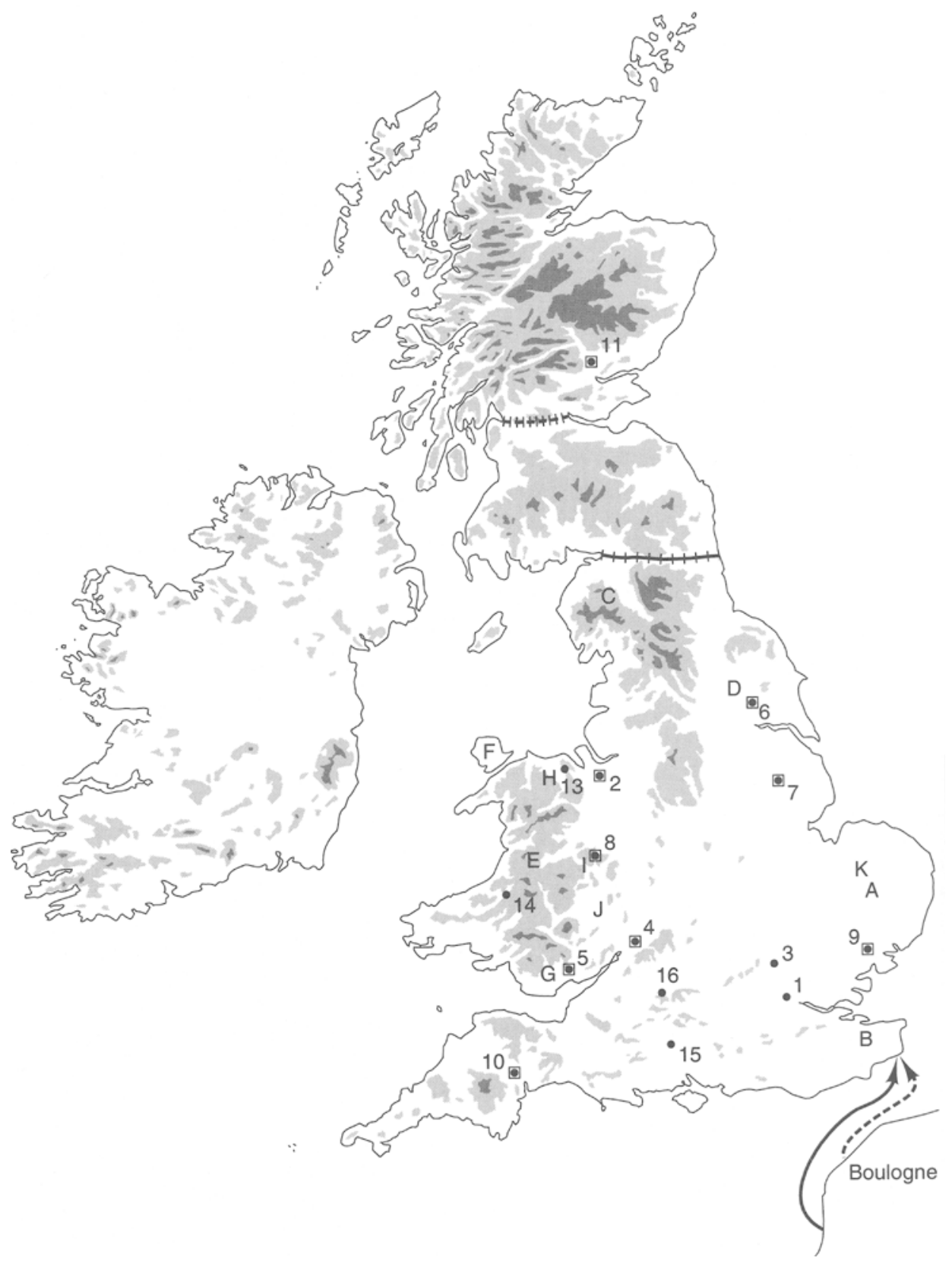




\section{ROMAN BRITAIN}

- Places

1 London

2 Chester

6 York

7 Lincoln

11 Inchtuthil

3 St Albans

8 Wroxeter

9 Colchester

4 Gloucester

10 Exeter

13 Halkyn

14 Dolaucothi

15 Stonehenge

5 Caerleon

16 Avebury

Areas
A Suffolk
E Wales
I Shropshire
B Kent
F Anglesey
$\checkmark$ Hereford
C Cumbria
G Glamorgan
$\mathrm{K}$ East Anglia
D Yorkshire
$\mathrm{H}$ Clwyd

$\square$ Legionary fortresses

not all occupied at once

$+\mathrm{HHH+F}$ Antonine Wall

+++ Hadrian's wall

$\longrightarrow$ Caesar's invasion route in 55 and 54 BC

$-\rightarrow$ Claudius's invasion route in 43 AD

$\square$ Over $200 \mathrm{~m}$

ए Over $500 \mathrm{~m}$ 


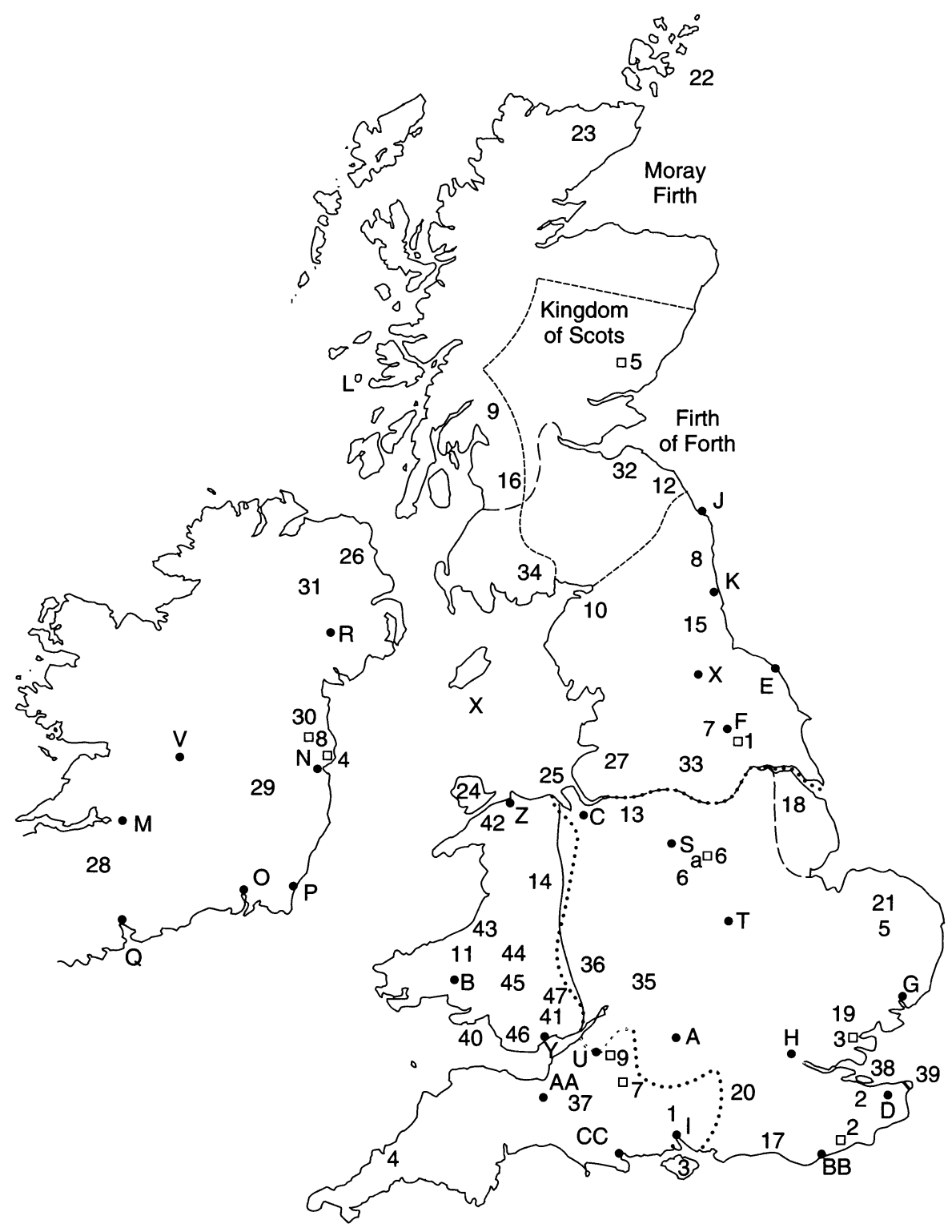




\section{ANGLO-SAXON BRITAIN}

- Places
A Dorchester-
H London
P Wexford
Y Caerleon
on-Thames
I Southampton
Q Cork
B Carmarthen
$J$ Lindisfarne
R Armagh
$\mathrm{K}$ Jarrow
S Derby
$Z$ Degannwy
C Chester
$\mathrm{L}$ Iona
D Canterbury
$T$ Leicester
$U$ Bath
E Whitby
M Limerick
$N$ Dublin
York
O Waterford
$\checkmark$ Clonmacois
$X$ Catterick
AA Athelney
BB Pevensey
CC South Cadbury

Areas

1 Hampshire

13 Cheshire

14 Powys

2 Kent

15 Northumbria

3 Isle of Wight

16 Strathclyde

4 Cornwall

5 East Anglia

17 Sussex

6 Mercia

7 Deira

18 Lindsey

19 Essex

8 Bernicia

20 Surrey

9 Argyll

10 Cumbria

21 Norfolk

22 Orkney

23 Caithness

11 Dyfed

24 Anglesey

25 Wirral

26 Antrim

27 Lancashire

28 Munster

29 Leinster

30 Meath

31 Ulster

32 Lothian

33 Elmet

34 Rheged

35 Hwicce

36 Magonsaetan

37 Wessex

38 Sheppey

39 Thanet

40 Gower

41 Gwent

42 Gwynedd

43 Ceredigion

44 Builth

45 Brycheiniog

46 Glywysing

47 Ergyng

12 Gododdin

- Battles

1 Stamford Bridge

6 Repton

2 Hastings

3 Maldon

7 Edington

4 Clontarf

8 Tara

5 Nechtansmere

9 Wroughton

Boundary of Mercia in $\mathbf{8 0 0}$

- Boundary of Northumbria in 650

Boundary of Wessex in 830

Kingdom of Scots in 1018

— Offa's Dyke 


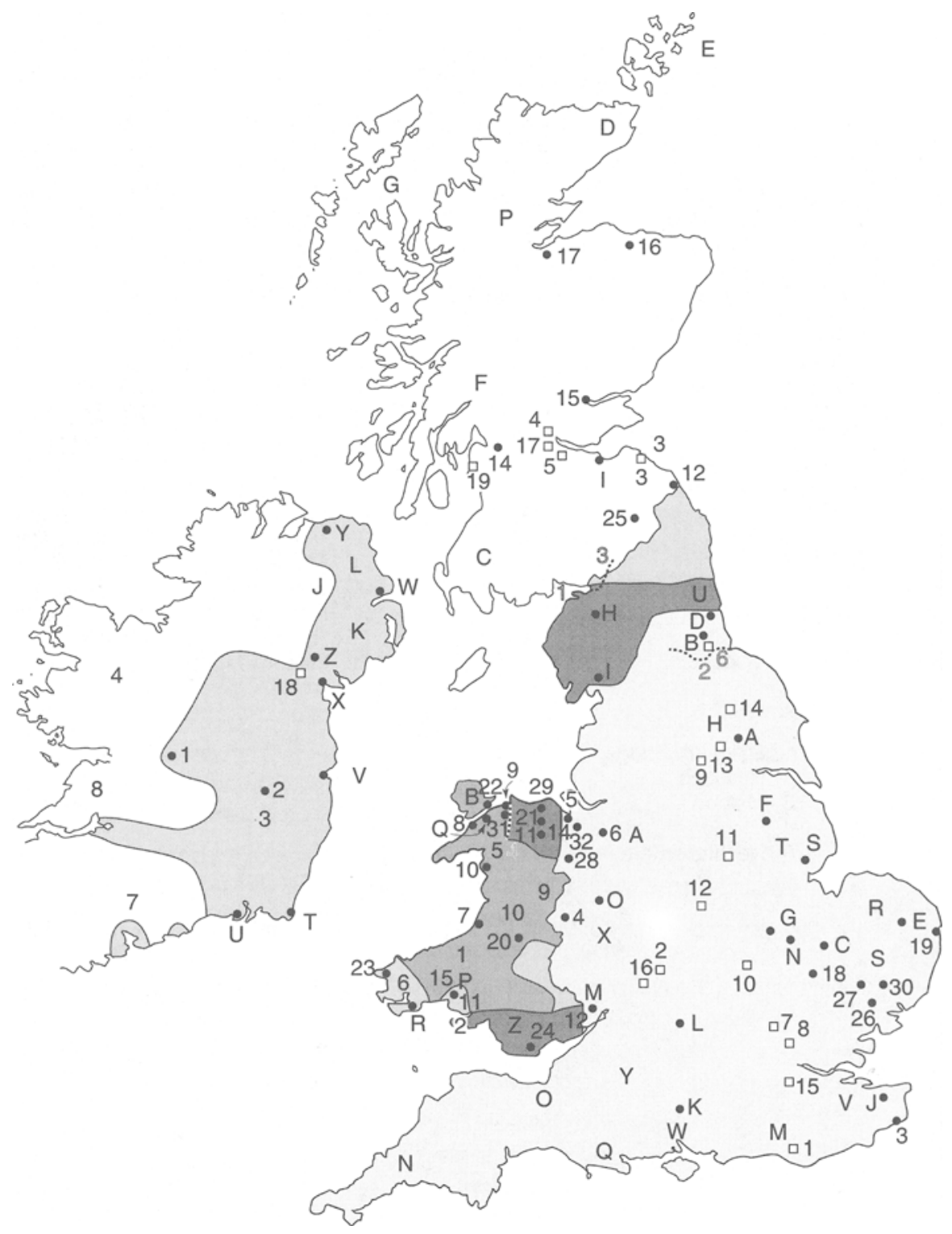




\section{MEDIEVAL BRITISH ISLES}

- Places

$\begin{array}{llcll}\text { A York } & \text { P Camarthen } & 6 \text { Chester } & 21 \text { St Asaph } \\ \text { B Durham } & \text { Q Bangor } & 7 \text { Aberystwyth } & 22 \text { Beaumaris } \\ \text { C Ely } & \text { R Tenby } & 8 \text { Caernarfon } & 23 \text { St Davids } \\ \text { D Newcastle } & \text { S Boston } & 9 \text { Conwy } & 24 \text { Llandaff } \\ \text { E Norwich } & \text { T Wexford } & 10 \text { Harlech } & 25 \text { Roxburgh } \\ \text { F Lincoln } & \text { U Waterford } & 11 \text { Denbigh } & 26 \text { Hadleigh } \\ \text { G Stamford } & \text { V Dublin } & 12 \text { Berwick } & 27 \text { Long Melford } \\ \text { H Carlisle } & \text { W Carrickfergus } & 13 \text { Edinburgh } & 28 \text { Holt } \\ \text { I Kendal } & \text { X Dundalk } & 14 \text { Glasgow } & 29 \text { Rhuddlan } \\ \text { J Canterbury } & \text { Y Coleraine } & 15 \text { Perth } & 30 \text { Lavenham } \\ \text { K Winchester } & \text { Z Newry } & 16 \text { Elgin } & 31 \text { Degannwy } \\ \text { L Dorchester- } & 1 \text { Athlone } & 17 \text { Inverness } & 32 \text { Hawarden } \\ \quad \text { on-Thames } & 2 \text { Kildare } & 18 \text { Cambridge } & \\ \text { M Tintern } & 3 \text { Dover } & 19 \text { Great } & \\ \text { N Peterborough } & 4 \text { Montgomery } & & \text { Yarmouth } & \\ \text { O Shrewsbury } & 5 \text { Flint } & 20 \text { Builth } & \end{array}$

Regions

$\begin{array}{ll}\text { A Cheshire } & \text { L Antrim } \\ \text { B Anglesey } & \text { M Sussex } \\ \text { C Galloway } & \text { N Cornwall } \\ \text { D Caithness } & \text { O Somerset } \\ \text { E Orkney } & \text { P Ross } \\ \text { F Argyll } & \text { Q Dorset } \\ \text { G Western Isles } & \text { R Norfolk } \\ \text { H Yorkshire } & \text { S Suffolk } \\ \text { I Lothian } & \text { T Lincolnshire } \\ \text { J Ulster } & \text { U Northumbria } \\ \text { K Down } & \text { V Kent }\end{array}$

W Hampshire

$X$ Herefordshire

$Y$ Wiltshire

Z Glamorgan

1 Ceredigion

2 Gower

3 Leinster

4 Connacht

5 Gwynedd

6 Pembrokeshire

7 Desmond

8 Thomond

9 Powys

10 Deheubarth

11 Kidwelly

12 Gwent

13 Moray

14 Clwyd

15 Dyfed

Battles

1 Lewes

2 Evesham

3 Dunbar

4 Stirling

5 Falkirk

6 Neville's Cross

7 St Albans

$\begin{aligned} 8 & \text { Barnet } \\ 9 & \text { Wakefield } \\ 10 & \text { Northampton } \\ 11 & \text { Stoke } \\ 12 & \text { Bosworth } \\ 13 & \text { Towton } \\ 14 & \text { Boroughbridge }\end{aligned}$

8 Barnet

10 Northampton

15 Sevenoaks

16 Tewkesbury

17 Bannockburn

18 Faughart

19 Largs
Rivers .......

1 Solway Firth (bay)

2 Tees

3 Liddel

4 Conway

Areas under effective control of the English crown and its subjects at the death of William I, 1087. Additions to this area by 1189 Additions to this area by 1290 Additions to this area by 1100 


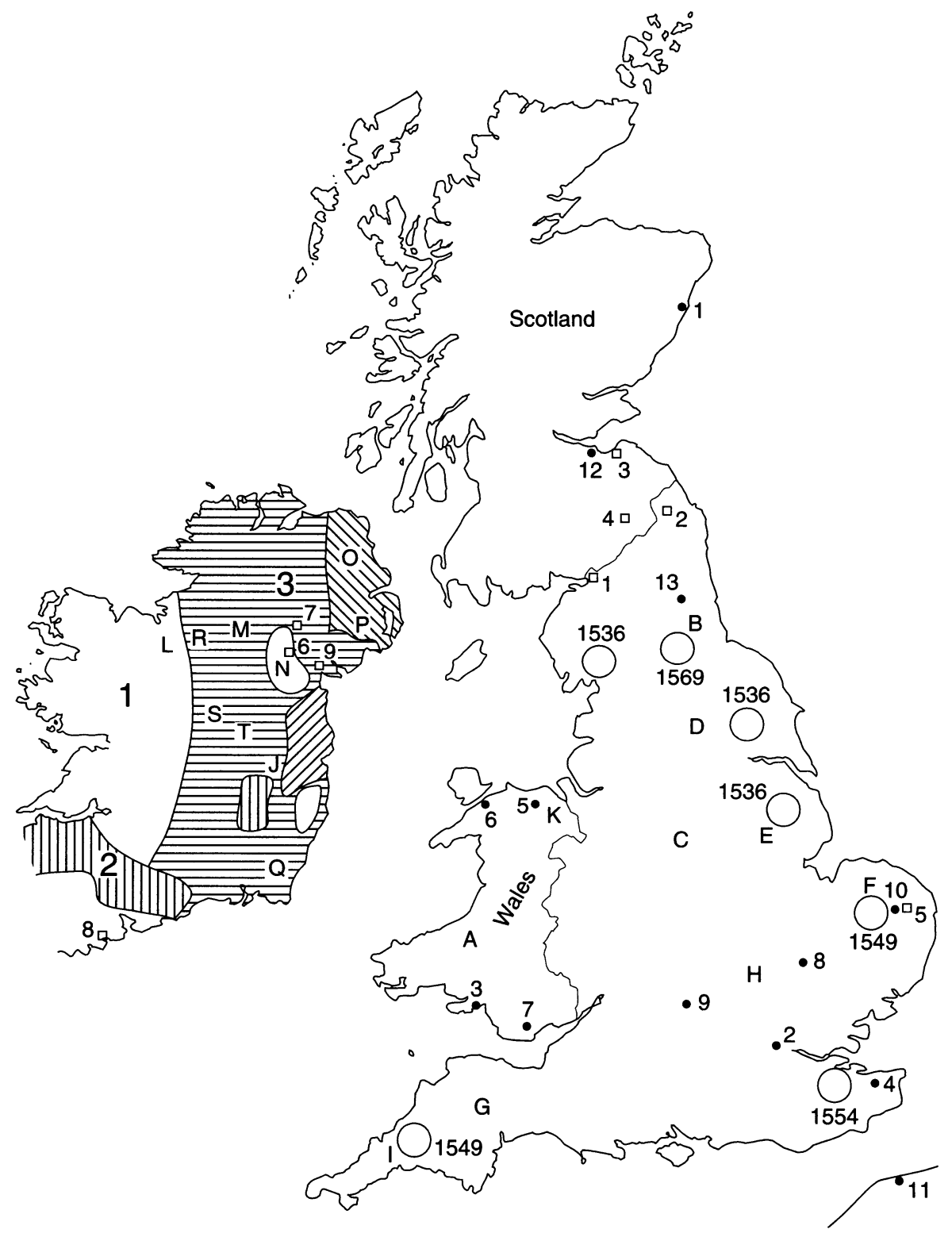

xxiv 


\section{THE SIXTEENTH CENTURY}

- Places

1 Aberdeen

2 London

6 Bangor

7 Llandaff

11 Calais

3 Swansea

4 Canterbury

8 Cambridge

9 Oxford

5 St Asaph

10 Norwich

12 Edinburgh

13 Durham

Counties
A Cardiganshire
H Bedfordshire
B Durham
I Cornwall
$\mathrm{J}$ Kildare
K Flintshire
C Derbyshire
L Sligo
E Lincolnshire
$M$ Fermanagh
F Norfolk
$\mathrm{N}$ Monaghan

O Antrim

口 Battles

Regions (larger

1 Solway Moss

6 Clontibret than counties)

2 Flodden

7 Yellow Ford

8 Kinsale

9 Moyry Pass

$P$ Down

Q Wexford

R Leitrim

$S$ Longford

$\mathrm{T}$ Westmeath

4 Ancrum Moor

5 Dussindale

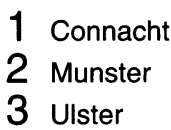

Centres of Rebellion

in England

The Pale c. 1550

Plantations established before 1603

Scottish settlements

Plantations

established 1603-49 


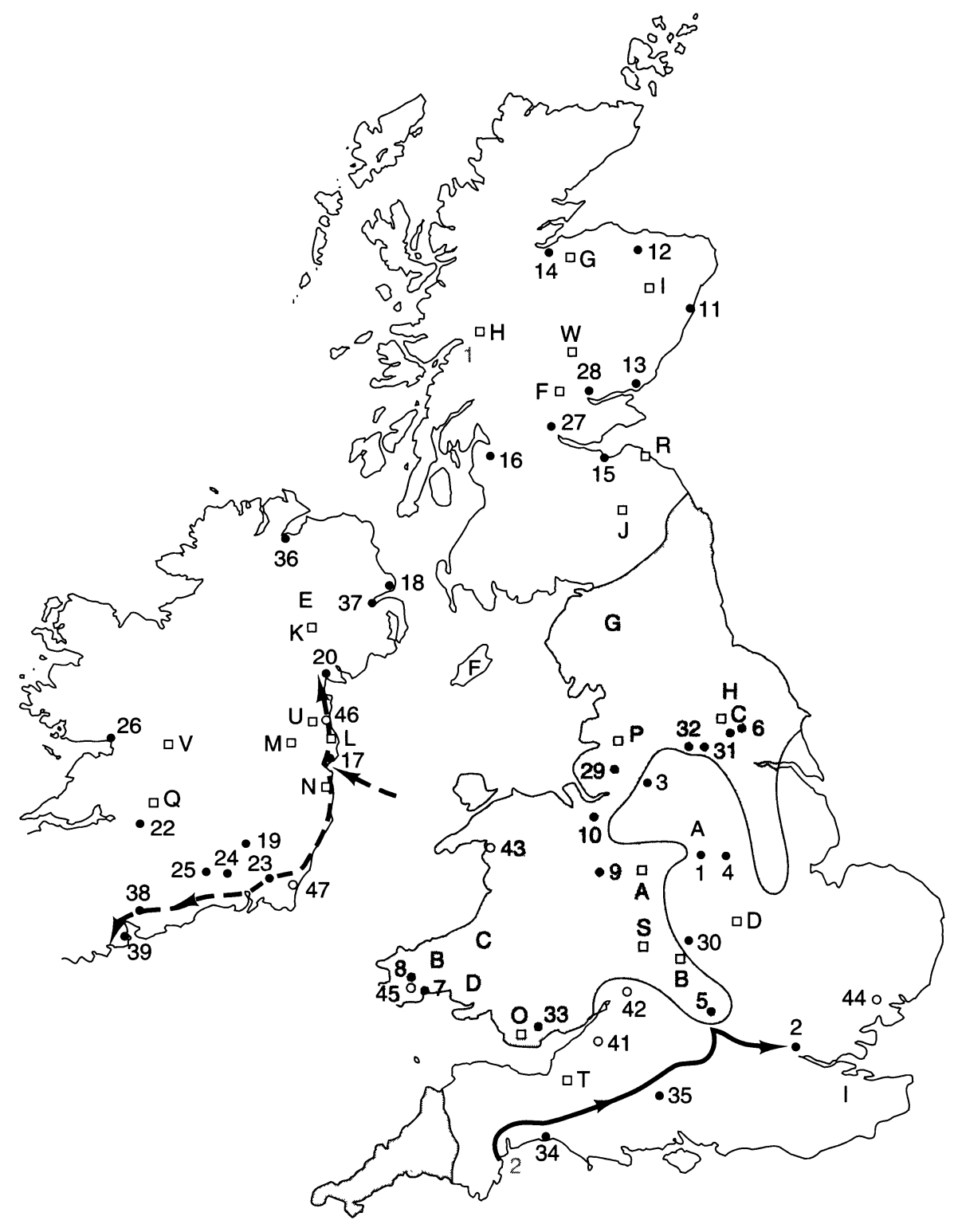


THE CIVIL WARS $1638-1691$

- Towns

1 Derby

2 London

3 Manchester

4 Nottingham

5 Oxford

6 York

7 Tenby

8 Haverfordwest

9 Shrewsbury

10 Chester

- Battles
A Hopton Heath 1643
B Edgehill 1642
C Marston Moor 1644
D Naseby 1645
F Tippermuir 1644
G Auldearn 1645
H Inverlochy 1645
I Alford 1645

- Besieged Towns

41 Bristol 1643

42 Gloucester 1643

43 Harlech 1647

44 Colchester 1648

45 Pembroke 1648

46 Drogheda 1649

47 Wexford 1649
11 Aberdeen

12 Elgin

13 Dundee

14 Inverness

15 Edinburgh

16 Glasgow

17 Dublin

18 Carrickfergus

19 Kilkenny

20 Dundalk
22 Limerick

23 Ross

24 Carrick

25 Clonmel

26 Galway

27 Stirling

28 Perth

29 Wigan

30 Warwick

31 Leeds
32 Bradford

33 Llandaff

34 Lyme Regis

35 Salisbury

36 Derry

37 Belfast

38 Cork

39 Kinsale
J Philiphaugh 1645
K Benburb 1646
L Julianstown 1641
M Dungan Hill 1647
N Baggot-rath 1649
O St Fagan's 1648
P Preston 1648
Q Scarrifhollis 1650

Areas

A Derbyshire

B Pembrokeshire

C Cardiganshire

D Carmarthenshire

E Ulster

$\mathrm{F}$ Isle of Man

G Cumberland
R Dunbar 1650

S Worcester 1651

T Sedgemoor 1685

U Boyne 1690

V Aughrim 1691

W Killiecrankie 1689

Areas of Royalist support in England and Wales 1 May 1643

\section{Campaigns}

William of Orange's route in 1688

Cromwell's route in 1649 


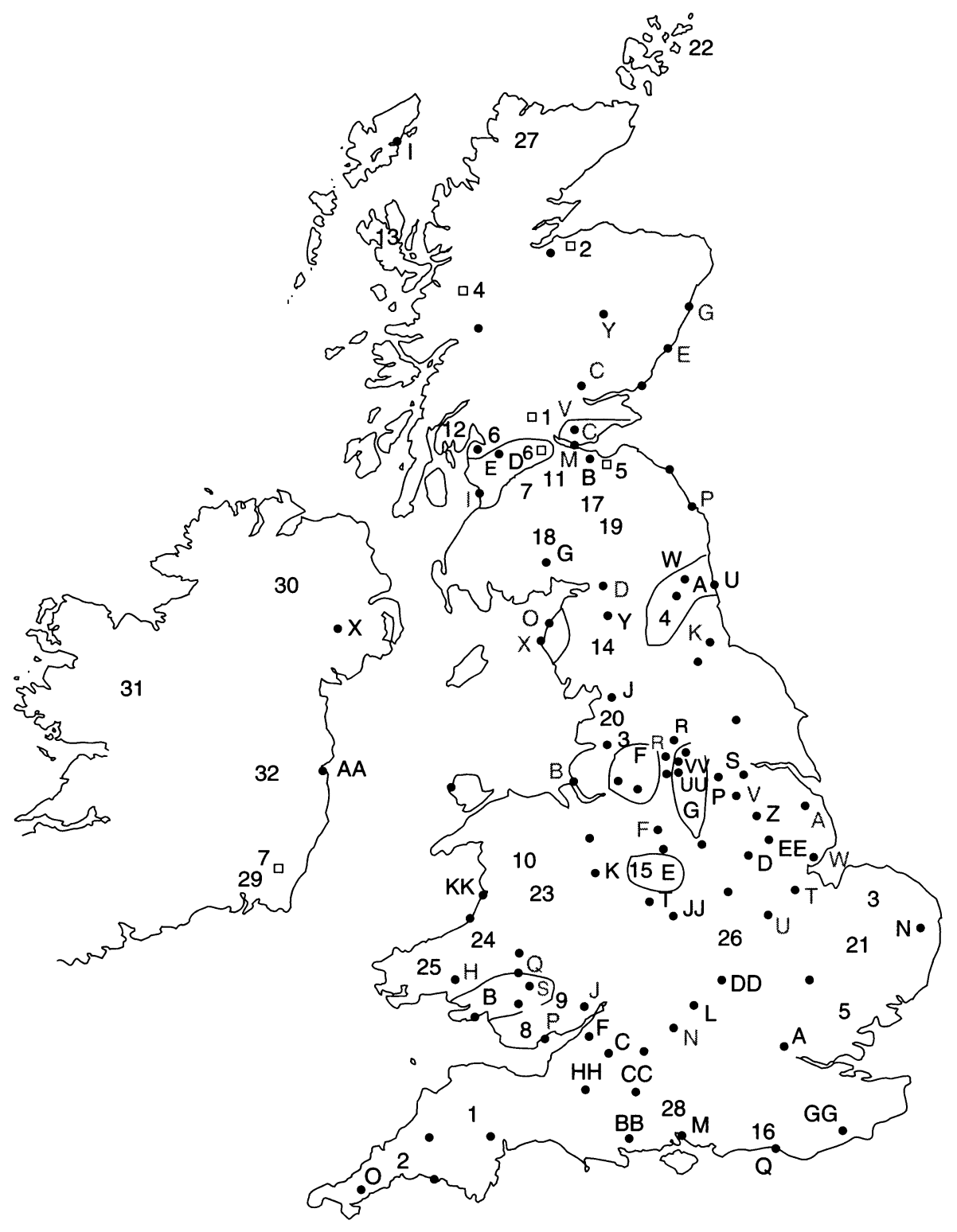


BRITAIN OF INDUSTRIALIZATION \& REFORM 1750 - 1900

- Places

$\begin{array}{rlll}\text { A London } & \text { O Truro } & \text { I Troon } & \text { Darlington } \\ \text { AA Dublin } & \text { P Doncaster } & \text { J Tintern } & \text { Exeter } \\ \text { B Edinburgh } & \text { Q Brighton } & \text { K Stockton } & \text { Holyhead } \\ \text { BB Wimborne } & \text { R Bradford } & \text { L Plymouth } & \text { Crewe } \\ \text { C Bath } & \text { S Scunthorpe } & \text { M Forth Bridge } & \text { Gateshead } \\ \text { CC Wilton } & \text { T Birmingham } & \text { N Swindon } & \text { Burton-on-Trent } \\ \text { D Grantham } & \text { U Sunderland } & \text { O Workington } & \text { Huddersfield } \\ \text { DD Wolverton } & \text { UU Dewsbury } & \text { P Bambrugh } & \text { Nottingham } \\ \text { E Glasgow } & \text { V Dunfermline } & \text { Q Merthyr Tydfil } & \text { Leicester } \\ \text { EE Sleaford } & \text { VV Batley } & \text { R Halifax } & \text { Leeds } \\ \text { F Bristol } & \text { W Newcastle } & \text { S Ebbw Vale } & \text { Cardiff } \\ \text { G Dumfries } & \text { X Carrickfergus } & \text { T Spalding } & \text { Rhondda } \\ \text { GG Battle } & \text { Y Penrith } & \text { U Stamford } & \text { Brecon } \\ \text { HH Bruton } & \text { Z Lincoln } & \text { V Gainsborough } & \text { Dundee } \\ \text { I Stornoway } & \text { A Louth } & \text { W Boston } & \text { Fort William } \\ \text { J Lancaster } & \text { B Liverpool } & \text { X Whitehaven } & \text { Bolton } \\ \text { JJ Stoneleigh } & \text { C Perth } & \text { Y Braemar } & \text { Devizes } \\ \text { K Shrewsbury } & \text { D Carlisle } & \text { Inverness } & \text { Berwick } \\ \text { KK Aberdovey } & \text { E Montrose } & \text { Manchester } & \text { Cambridge } \\ \text { L Oxford } & \text { F Derby } & \text { York } & \text { Launceston } \\ \text { M Southampton } & \text { G Aberdeen } & \text { Aberystwyth } & \\ \text { N Norwich } & \text { H Carmarthen } & \text { Swansea } & \end{array}$

Regions

1 Devon

2 Cornwall

3 Norfolk

4 Durham

5 Essex

6 Strathclyde

7 Lanarkshire

8 Glamorgan

9 Monmouthshire

10 Merioneth

11 Midlothian

12 Renfrew

13 Skye

14 Lake District

15 Black Country

16 Sussex

17 Selkirk

18 Dumfries

19 Roxburghshire

20 Lancashire

21 East Anglia

22 Orkney Islands

23 Montgomeryshire

24 Cardiganshire

25 Pembrokeshire

26 Northamptonshire

27 Sutherland

28 Hampshire

29 Wexford

30 Ulster

31 Connacht

32 Leinster

口 Battles

1 Sheriffmuir 1715

2 Culloden 1746

3 Preston 1716

4 Glenshiel 1719

5 Prestonpans 1745

6 Falkirk 1746

7 Vinegar Hill 1798

Major Coalfields
(A) North-East
(B) South Wales
(C) Fife

(D) Strathclyde

(E) Midlands

(G) Nottinghamshire/Yorkshire

xxix 


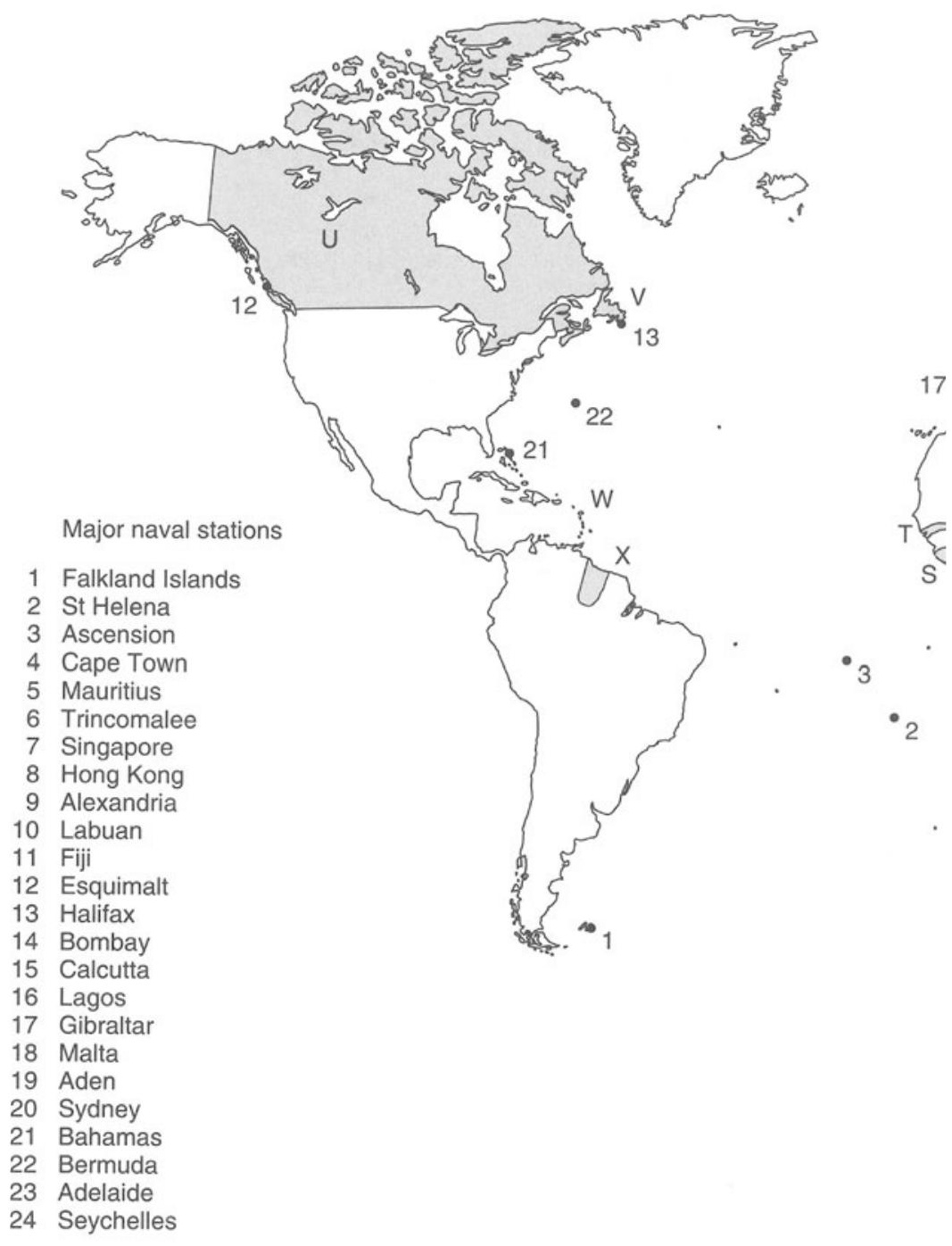




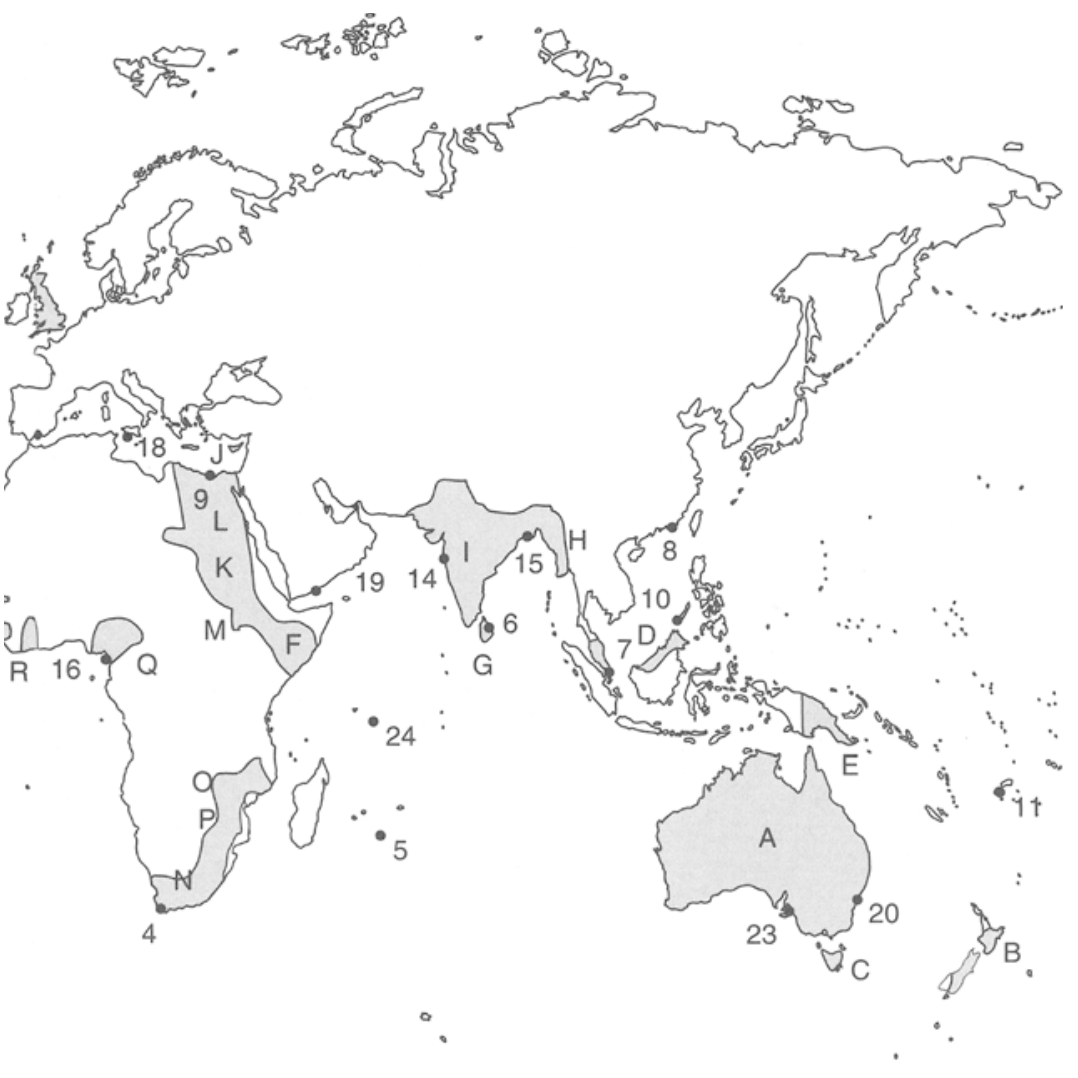
A Australia
I India
B New Zealand
$J$ Cyprus
Q Nigeria
C Tasmania
K Sudan
D Malaya
L Egypt
R Gold Coast
E New Guinea
M Uganda
S Sierra Leone
T Gambia
U Canada
$F$ Kenya
N S. Africa
V Newfoundland
G Ceylon
O N. Rhodesia
W British West Indies
H Burma
P S. Rhodesia
X British Guiana 